\title{
The Buddhist Perspective on the Beginning of the World, Nature, God, and Destruction
}

\section{By Widiyono}

The discussion on the beginning of the world, nature, God, and destruction is always an interesting topic. Especially, if we analyze the topic based on certain religious perspective, it will enrich our understanding about the topic as seen from the point of view of the religion which we refer to. There may be abundant resources which have described analytically about the beginning of the world, nature, God, and destruction from Islamic and Christian standpoints. However, it is hardly found any reading materials which clarify those subjects from the approach of Buddhism. Since there must be certain concepts found in the Buddhist scripture related to the subjects, obviously we can discuss those themes as viewed from Buddhism. By doing this, at least, we will understand what Buddhism would say with regard to those issues. In spite of the absence of the concept of God in Buddhism, we can see the view of the beginning of the world, nature, and destruction in the Buddhist texts. Therefore, in this paper I will examine how Buddhism perceives the concept of God, the beginning of the world, nature, and destruction by referring to the Buddhist scriptures. Here I will include the exposition of how Buddhist concept about the beginning of the world in relevance with the human role, nature, and the destruction of nature.

As we see in our daily life, in this modern era we are facing various kinds of alarming problems. Environmental problems are just few of them. While there are various perspectives in perceiving the existing of environmental problems, religions also have their own perspectives in this case. In such an attempt, Buddhism is not the exception. Although the concept of the beginning of the world, nature, God, and destruction found in Buddhism may differ from those are found in Islam, Christianity or other religious traditions, it is interesting to see the Buddhist scripture discuss about those things. By doing so, we can see, for example, what Buddhism could say about the beginning of the world in relevance with human role, natural world, and divine.

There are reasons why I like to discuss about the topic. First of all, like other religious texts belonging to other religions, Buddhist texts in certain case contain myth and legendary elements which probably are far from historical facts. However we may still need the mythological and the legendary accounts, since in certain extent they can control human behavior. As we understand, in order to behave in a certain way, human beings usually need a 
certain method to carry on. In such a case, a religious discourse can really play an important role for establishing better people or better society. Secondly, there are only very few scholars who have investigated the perspective of Early Buddhism towards any human problems including environmental problems. In actual fact, when we explore early Buddhist scripture, there are scattered references found there that can be contributed to solve the problems. Especially with regard to environmental problems, in the scripture, we find that there is a psychological as well philosophical basis that can be interpreted as an important foundation for solving of environmental problems. Moreover, there are also verses found in the scripture which were uttered by the Buddha and his disciples in appreciation to the beauty of the nature or environment where they lived close by. Therefore, in spite of the non-existence of the environmental problem especially when the early scripture was written down, we can use its environmental philosophy to give some hints to prevent or to solve any environmental problems.

Buddhist scholars usually use the term early Buddhism ${ }^{1}$ in order to distinguish it with later form of Buddhism. As we know, as a religion and philosophy since its inception, Buddhism has undergone many changes. It is quite natural that any system of thought should go through such a changes, and undergo development in the course of history of its inception. As expected in any system of thought, the original teaching of the Buddha has been subjected to various interpretations by the followers of the teaching themselves. As time went on, various schools of Buddhism came to be formed on the basis of particular interpretations which they give to the teaching of the Buddha. Such a situation led to the existence of numerous schools found in Buddhism. Therefore, usually Buddhist scholars will identify the existing of those Buddhist schools as later forms of Buddhism.

So, what is meant by early Buddhism is a form of Buddhism before it split to various schools. Buddhist scholars identify it by comparing the existing of all Buddhist scriptures from various tradition, and then finding the common core or common feature among them. From here, we can also understand that what is meant by early Buddhist texts are the Buddhist texts which are in common in every Buddhist school or tradition, since every school of Buddhism has their own religious texts.

\footnotetext{
${ }^{1}$ Kalupahana, David J., 1976, Buddhist Philosophy A Historical Analysis. Honolulu: The University Press of Hawaii, p. xi-xv
} 


\section{The Buddhist view on (Creator) God}

Before I discuss the concept of the beginning of the world, nature, and destruction or the end of the world, it will be better if I relate the concept of God in Buddhist perspective. Here, we will see that especially in Indonesia, the early stage of Buddhism has different notion about the concept of God comparing with later form of Buddhism. There is some kind of negotiation adopted by Indonesian Buddhism to accomplish the social and political background in which Buddhism establishes. However first of all, I will discuss about the early Buddhist perspective on the concept of God before finally I relate it in the later form of Buddhism, especially in Indonesian case.

It is worthy of note to see the perspective of early Buddhism on God or divinity. Comparing with other religions, early Buddhism can be said that it is very different from other religious systems. Especially when we refer to the notion of God, the Creator of the universe or the so called Supernatural Being, early Buddhism will have different answers, especially with those of theistic religions.

As stated above, some scholars identify the term early Buddhism as Buddhism which is in the stage before it split into various schools. According to them, this can be identified by searching the common core or characteristic after comparing all the scriptures belonging to all school of Buddhism. After comparing the content of those scriptures finally scholars can find out the common characteristic of all school of Buddhism which can be interpreted as early Buddhist teaching, because the teachings can be found in all those traditions or schools.

There are three characteristics which are regarded as early Buddhism. First of all, early Buddhism never emphasizes on the importance of depending on authority, like scripture, tradition, logic, teacher and so on. It emphasizes more on knowledge based on one's own experience, especially the super cognitive experience. Secondly, early Buddhism does not emphasize on the notion of absolutism. The search for absolutism is regarded as the source of both psychological conflict and other worldly conflict. Therefore, the emphasis is on the searching for inner peace. Lastly, early Buddhism never tries to discuss the concept of metaphysical things like the origin of the world, the beginning of the world and etc. According to early Buddhism, the effort to find out the answer of those metaphysical things will not lead to attainment of inner peace or liberation from suffering. Therefore the approach used by early 
Buddhism is more on pragmatist approach, namely understanding the existence of the problem and finding out the solution of it.

Based on the above mentioned clarification, at least we get some glimpse about early Buddhist view on God. In its earliest form, Buddhism was agonistic with the idea of the so called Supreme Deity which can be identified as God. For instance, in one of the Buddha's discourses, there is statement said by the Buddha as follows:

"There are certain recluses and Brahmins who hold the view: "Whatsoever weal or woe or neutral feeling is experienced, all that is due to the creation of Supreme Deity. "Then I say to them: "So then, owing to the creation of a Supreme Deity, men will become murderers, thieves, unchaste, liars, slanderers, abusive, babblers, covetous, malicious, malicious, and preserve in view. Thus for those fall back on the creation of a Supreme Deity as the essential reason there neither desire to do, nor effort to do, nor necessity for action or inaction not being found to exist in truth and verity, the term "recluse" cannot reasonably be applied to yourselves, since you live on a state of bewilderment with faculties unwarded."

On another occasion, there is also statement in the Jataka which says that this world which is full of sorrow and evil cannot be created by a God (Brahma) who is good and almighty. ${ }^{3}$ Still on another event, the Buddha also denies the doctrine of Brahmanism that there is God who cannot be seen, and rejects that their traditions alleged to be founded on revelation have any basis, for these traditions are forwarded by one generation to the other included in the scripture of lore; but no Brahmin can say that he speaks from his own experience. ${ }^{4}$ Thus, in the earlier form, early Buddhism never emphasizes on the concept of God, though of course emphasis on the importance of morality, peace, and other wholesome thing. In other words, in early Buddhism, the concept of God or Supreme Deity never becomes the central notion.

There is also another instance found in the Buddhist scripture which talks about a being who claims himself to be Brahmā, the Great Brahmā, the Vanquisher, the Unvanquished, the Universal Seer, the Wielder of Power, the Lord, the Maker and Creator, the Supreme Being, the Ordainer, the Almighty, the Father of all that are and are to be. ${ }^{5}$ The text actually refers to some recluses and Brahmins who are eternalists in regard to some things and non-eternalists in regard to other things, and who on four grounds proclaim the self and the world to be partly eternal and

\footnotetext{
${ }^{2}$ Woodwards, F.L (Translt.) 1932. The Book of Gradual Sayings Vol. !. London: Pali Text Society. P 158

${ }^{3}$ Fausboll, V. (ed). 1962, Jataka, Vol V. London: Pali Text Society. P 158

${ }^{4}$ Nanamoli, Bhikkhu and Bhikkhu Bodhi. 1995. The Middle Length Saying of Buddha. Kandy: Buddhist Publication Society. p. 779

${ }^{5}$ Walshe, Maurice. 1995. The Long Discourse of the Buddha. Kandy: Buddhist Publication Society. pp. 75-76
} 
partly non-eternal. In this text, such a kind of view is considered as one of 62 misleading views existing during the Buddha's time. So, it is in a way that Buddhism criticizes such a view. The text mentions as follows;

"There comes a time, bhikkhus, when after the lapse of a long period this world contracts (disintegrates). While the world is contracting, beings for the most part are reborn in the Ābhassara Brahma-world. ${ }^{6}$ There they dwell, mind-made, feeding on rapture, selfluminous, moving through the air, abiding in glory. And they continue thus for a long, long period of time.

"But sooner or later, bhikkhus, after the lapse of a long period, there comes a time when this world begins to expand once again. While the world is expanding, an empty palace of Brahmā appears. Then a certain being, due to the exhaustion of his life-span or the exhaustion of his merit, passes away from the Ābhassara plane and re-arises in the empty palace of Brahmā. There he dwells, mind made, feeding on rapture, self-luminous, moving through the air, abiding in glory. And he continues thus for a long, long period of time.

"Then, as a result of dwelling there all alone for so long a time, there arises in him dissatisfaction and agitation, (and he yearns): 'Oh, that other beings might come to this place!' Just at that moment, due to the exhaustion of their life-span or the exhaustion of their merit, certain other beings pass away from the Ābhassara plane and re-arise in the palace of Brahmā, in companionship with him. There they dwell, mind-made, feeding on rapture, self-luminous, moving through the air, abiding in glory. And they continue thus for a long, long period of time.

"Thereupon the being who re-arose there first thinks to himself: 'I am Brahmā, the Great Brahmā, the Vanquisher, the Unvanquished, the Universal Seer, the Wielder of Power, the Lord, the Maker and Creator, the Supreme Being, the Ordainer, the Almighty, the Father of all that are and are to be. And these beings have been created by me. What is the reason? Because first I made the wish: "Oh, that other beings might come to this place!" And after I made this resolution, now these beings have come.'

"And the beings who re-arose there after him also think: 'This must be Brahmā, the Great Brahmā, the Vanquisher, the Unvanquished, the Universal Seer, the Wielder of Power, the Lord, the Maker and Creator, the Supreme Being, the Ordainer, the Almighty, the Father of all that are and are to be. And we have been created by him. What is the reason? Because we see that he was here first, and we appeared here after him.'

"Herein, bhikkhus, the being who re-arose there first possesses longer life, greater beauty, and greater authority than the beings who re-arose there after him.

\footnotetext{
${ }^{6}$ In Buddhism, it is understood as one of 31 realms which is attained by those who have cultivated certain mental development. Cosmologically, it is above human beings, because it is one of the 26 heavens. Abhassara means the Radiant Ones. They are a class of heavenly beings of the fine-material world.
} 
"Now, bhikkhus, this comes to pass, that a certain being, after passing away from that plane, takes rebirth in this world. Having come to this world, he goes forth from home to homelessness. When he has gone forth, by means of ardor, endeavor, application, diligence, and right reflection, he attains to such a degree of mental concentration that with his mind thus concentrated he recollects his immediately preceding life, but none previous to that. He speaks thus: 'We were created by him, by Brahmā, the Great Brahmā, the Vanquisher, the Unvanquished, the Universal Seer, the Wielder of Power, the Lord, the Maker and Creator, the Supreme Being, the Ordainer, the Almighty, the Father of all that are and are to be. He is permanent, stable, eternal, not subject to change, and he will remain the same just like eternity itself. But we, who have been created by him and have come to this world, are impermanent, unstable, short-lived, doomed to perish.",

It seems that the main purpose of the text is to disapprove a view held by those religious teachers at the time, because they always come to absolute truth claim which many cases, such a claim leads to the existence of dogmatism, quarrel, and conflict. ${ }^{8}$

In addition, Buddhism uses the concept of interconnectedness or dependent origination to explain everything which happens in nature. It is considered as a natural law which governs the universe. The formula of this law is stated thus, "When this is present, that comes to be; from the arising of this, that arises. When this is absent, that does not come to be; on the cessation of this, that ceases." ${ }^{9}$ In Buddhism, this formula is used to explain the occurrence and the disappearance of every phenomenon. It is regarded as the central teaching of Buddhism, because most of all the Buddha's teachings are based on this doctrine. Moreover, it is in a way in which Buddhism rejects the notion of first cause (causa prima) and the idea of only a single factor which is responsible for the occurrence of everything. ${ }^{10}$ According to Buddhism, everything can be explained in term of dependent origination or interconnectedness. That is why Buddhism maintains that there is nothing which is not governed by the law of dependent origination. $^{11}$

However, when we come to the history of Buddhism in modern Indonesia, there is a different paradigm about the notion of God among Buddhist people in Indonesia. Especially during the early period of the Suharto's regime there was necessity that all religions must have

\footnotetext{
${ }^{7}$ Walshe, Maurice. 1995. The Long Discourse of the Buddha. Kandy: Buddhist Publication Society. pp. 75-76

${ }^{8}$ Andersen, D and H. Smith (ed). 1913. The Sutta Nipata. London: Pali Text Society. V 878

${ }^{9}$ Bodhi, Bhikkhu. 2000. The Connected Discourse of the Buddha; a New Translation of the Samyutta Nikaya.

Boston: Wisdom Publications. pp. 552

${ }^{10}$ Ibid. pp 533-552

${ }^{11}$ Kalupahana, D.J. 1999. The Buddha and the Concept of Peace. Sri Lanka: Sarvodaya Vishva Lekha Publications. p. 5
} 
the concept of God or divinity which is in accordance with the first precept of Pancasila. In other words, there is an emphasis that five religions which have been recognized by the government namely Islam, Christian Protestant, Christian Catholic, Hinduism, and Buddhism had to show each of their concept of God.

For Islam and Christianity, they might have no problem at all about the notion of God. However, at the time Buddhism and Hinduism had to try hard to make some kind of adjustment with the government policy. Otherwise their existence will be banned. Thus Hinduism then formulated the concept of Sanghyang Widi Wasa to accommodate the concept Ketuhanan Yang Maha Esa (Belief in the One and Only God), whereas in Buddhism, there occurred different alternatives formulated by each of school of Buddhism.

The first formulation given by one of Buddhist people to accommodate the concept of Belief in One and Only God was formulated by Ven. Ashin Jinarakhita. ${ }^{12}$ He was the founder of Buddhayana or Sangha Agung Indonesia, one of three Buddhist monastic organizations in Indonesia. He formulated the terms "Sanghyang Adi Buddha" for the concept of God in Buddhism. In his opinion, Adi Buddha is a term used to address the concept of Belief in One and Only God in Buddhism. Furthermore, he suggested that the address is derived from the Aisvarika tradition, sub-sect of Mahayana Buddhism in Nepal which spread to Benggala then arrived also in Jawa. In addition, in Jinarakkhita's view, the word "Aisvarika" is an address given by the Buddhist followers for the divinity or "Ketuhanan." This word is derived from the word 'Isvara' which means "God" or "Great Buddha" or The Almighty", and the suffix "ika" which means followers. Finally the followers of the school of Buddhism which was established and led by him until this time always uses the term "Sanghyang Adi Buddha" to address the God during their pray or doing any other religious activities. The school which was founded by him now is called Majelis Buddhyana Indonesia, and its Buddhist monk organization is called Sangha Agung Indonesia.

Until this time, Majelis Buddhayana Indonesia always tries to emphasize that the term Adi Buddha is also used by Buddhist followers of the school Svabhavavak existing in Nepal. This school is considered as one brach of Tantrayana which is included as one of the Mahayana

\footnotetext{
${ }^{12}$ http://majalah.tempointeraktif.com/id/arsip/1974/05/18/AG/mbm.19740518.AG64564.id.html accessed on the 22 of December 2010
} 
school. ${ }^{13}$ According to Majelis Buddhayana's opinion, this Svabhavavak school addresses the Almighty God by the name Adi Buddha. This idea then was introduced to Java, so the term Adi Buddha was also known in Buddhism which was introduced in Java in the era of Sriwijaya and Majapahit. According to this view, one can be united with (moksa) with Adi Buddha or Isvara by way of ascetism (tapa) and concentration (Samadhi or dhyana). Therefore, this school believes that Adi Buddha is the personification of divinity (Ketuhanan). However, the Buddhayana school recognizes that Buddhism in Indonesia does not regard the Almighty God as something personal (pribadi). Finally the school uses the idea of praising the One and Only God with the phrase "Namo Sanghyang Adi Buddhaya" which means Praise to the Almighty God or Homage to the Almighty God.

The Buddhayana school in Indonesia always tries to enforce the concept to other schools of Buddhism in Indonesia. The schools maintains that Adi Buddha was primordial Buddha, The Only One which is also called Paramadi Buddha (the first Buddha and the Incomparable One). According to this school, the other names for Adi Buddha are Anadi Buddha (the Buddha who is not created), Uru Buddha (the Buddha of all Buddhas), Adinatha (the First Refuge), Svayambhulokanatham (The Protector of the world who exist by himself), Vajradhara (the Holder of vajra), Vajrasattva (the Being of Vajra), Svayambhu (Who exist by Himself), atau Sanghyang Adwaya (There is no Second). ${ }^{14}$

The effort made by the Buddhayana School in Indonesia to maintain the existence of Belief in One and Only is not without any reaction. Some other Buddhist people or monks who did not agree with such an idea not only formulated other concepts but also make schism. That is why in Indonesia, each school of Buddhism has different concept to accommodate the concept of God. However, it seems that the accommodation of the concept of God in Indonesian, like in the earlier form of Buddhism, is never related to the notion of the beginning of the world.

\section{The Beginning of the World}

Actually Buddhism is never interested in the discussion on the beginning of the universe (loka), since in it is regarded as merely a metaphysical speculation which does not have any

13

http://www.scribd.com/doc/36895436/Adi\%C2\%A0Buddha\%C2\%A0Dalam\%C2\%A0Agama\%C2\%A0Buddha\%C 2\%A0Indonesia, accessed on 21 December 2010

${ }^{14}$ ibid 
pragmatic value to overcome problems faced by people. ${ }^{15}$ That is why in one of the discourses, the Buddha also says that the first beginning of the universe is not observable. ${ }^{16}$ However, as stated above, like other religious texts belonging to other religions, some Buddhist texts also contain myth and legendary elements. These myths or the legends sometimes were taken from the local or indigenous believes that were prevalent in India during the time of the Buddha. Those myths or the legends were used by the Buddha or his disciples to convey certain religious teaching. They are sometimes used to convey moral teaching advocated by the Buddha, and sometimes are used to reject certain teaching or religious believes belonging to other religions. The concept of mara whose literally means death or the killer is one of the examples of Buddhist mythology which is sometimes used to convey the idea of the tempter, the devil or the evil one. It symbolizes all that is connected to with the realm of rebirth and opposed to liberation from suffering. Commenting on this, T. O. Ling he says thus;

"It is remarkable fact, and one which is fully evident from a survey of the mythological element found in the Buddhist scriptures, that early Buddhism not only tolerated indigenous beliefs of the kind which have been described, but, as will appear in the next chapter, it went farther than this, from the materials which were readily available, so to speak, it produced its own characteristically and peculiarly Buddhist mythology of evil." 17

There are still many myths or legends which are scattered in the Buddhist texts, but probably the most famous Buddhist myth in Buddhist scholarship which was used by the Buddha to reject certain religious teaching belonging to other religion is what is stated in the Agganna sutta of the Digha Nikaya. Actually the main purpose of this discourse actually is to reject the notion of caste system which was advocated by Brahmanism rigidly. However, when we read carefully, the text can be used as a philosophical basis for the establishment of ecological conservation. Here the Buddha spoke about the evolutionary process of the origin of society which was usually misinterpreted by some scholar as the text which is discussed about the origin of the world according to Buddhism. The text depicts how the behavior or moral condition of the human being really has impacts towards their environmental condition. Moreover, here we will

\footnotetext{
${ }^{15}$ Nanamoli Bhikkhu dan Bhikkhu Bodhi (Transl.). 1995. The Middle Length Discourse of the Buddha; a New Translation of the Majjhima Nikaya. Kandy: Buddhist Publication Society. p. 533-536

${ }^{16}$ Feer, M.Leon (Ed). 1960. Samyutta Nikaya Vol. II London: Pali Text Society. 178.

${ }^{17}$ Ling, T.O. 1962. Buddhism and The Mythology of Evil. London: George Allen \& Unwin ltd. P. 30
} 
see that there in no involvement of the concept of God in the beginning of this earth according to Buddhism.

In this text, there is a description about the Buddha who had discussion with two of his disciples named Bharadvaja and Vasetha. It is said that they were ridiculed by their former Brahmanic friends for being converted to be the disciples of the Buddha. Their former friends said that both of them have fallen to the lower caste because of by becoming the disciples of the Buddha. To console both of them, finally the Buddha preached the sermon by using myth or legendary elements about the origin of the so called caste. Here is some extracts of the discourse as follows:

“....... There comes a time, Vasettha, when, sooner or later after a long period, this world contracts. At a time of contraction, beings mostly born in the Abhassara Brahma world. And there they dwell, mind made, feeding on delight, self luminous, moving through the air, glorious - and they stay like that for a very long time. But sooner or later, after a very long period, this world begins to expand again. At a time of expansion, the beings from the Abhassara Brahma world, having passed away from there, are mostly reborn in this world. Here they dwell, mind-made, feeding on delight, self-luminous, moving through the air, glorious - they stay like that for a very long time.

At that period, Vasettha, there was just mass of water, and all was darkness, blinding darkness. Neither moon nor sun appeared, no constellation or stars appeared, night and day were not distinguished, nor months and fortnight, nor years no seasons, and no male and female, beings being reckoned just beings. And sooner or later, after a very long period of time, savoury earth spread itself over the waters where those beings were. It looked just like the skin that forms itself over the hot milk as it cools. It was endowed with colour, smell and taste. It was the colour of fine ghee or butter, and it was very sweet, like pure wild honey.

Then, some being of greedy nature said, "I say, what can this be?" and tasted the savoury earth on its finger. In so doing, it became taken with the flavour, and craving arose in it. The other beings, taking their cue from that one, also tasted the stuff with their fingers. They too were taken with the flavour, and craving arose in them. So they set to with their hands, breaking off peaces of the stuff in order to eat it. And the result of this was that their self-luminance disappeared. And as a result of the disappearance of their selfluminance, the moon and the sun appeared, night and day were distinguished, months and fortnight appeared, the year and its seasons. To that extent the world reevolved..........."

\footnotetext{
${ }^{18}$ Walshe, Maurice. 1995. The Long Discourse of the Buddha. Kandy: Buddhist Publication Society. pp. 26-27
} 
From the above mentioned text, we can say that the above mentioned description used by the Buddha contains mythological elements. We can see that the chronology of the beginning of the world, food etc. as depicted in the text is far from historical fact and truth. There is a myth or legendarily element in it. We can say so, after referring the characteristics of myth as presented by Eliade in his book Myth and Reality. According to him, there are five characteristics in a myth, he says thus,

".......myth , as experienced by archaic societies, (1) constitutes the History of the acts of the Supernaturals; (2) that this History is considered to be absolutely true (because it is concerned with realities) and sacred (because it is the work of the Supernaturals); (3) that myth is always related to "creation," it tell how something came into existence, or how a pattern of behaviour, an institution, a manner of working were established; this is why myths constitute the paradigms for all significant human acts; (4) that by knowing the myth one knows the "origin" of things and hence can control and manipulate at will; this is not an "external," "abstract" knowledge but a knowledge that one "experiences" ritually, either by ceremonially recouting the myth or performing the ritual for which it is the justification; (5) that in one way or another one "lives" they myth, in the sense that one is seized by the sacred, exalting power of the events recollected or-reanacted."19

So, when we analyze the description of the above mentioned text, we can see that in the description there are some of the characteristics of myth as stated by Eliade. First of all, the above mentioned text described about "the History of the acts of the Supernaturals," although it may be somewhat different from the concept of those of theistic religions like Islam and Christianity. The text however mentions the involvement of the history or story of some divine beings which in the Buddhist context as stated above is Abhassara Brahma World. Those divine beings obviously are not human beings, but supernatural beings. Secondly, the history of the beginning of this world as described in the text, usually is considered as absolutely true by almost all Buddhist people, because in reality they can see that there is this world where they live in. However, it may be only very few who regarded the history or story as sacred thing, since the concept of sacred is hardly known in the Buddhist teaching. Thirdly, the description in above mentioned text also is also related to "creation" and tells how something came into existence, or how a pattern of behaviour, an institution, a manner of working were established. The texts obviously describe how the world and everything in it were established or were started. Of course the fourth and five characteristic as stated by Eliade may not be found here, but at least

\footnotetext{
${ }^{19}$ Eliade, Mircea. 1975. Myth and Reality. London: Harper Colophon Books. p. 18-19
} 
we have found three characteristics after analyzing the text. Therefore we can say that there are mythology elements in the Agganna sutta.

Another important point, the concept found in the text about the beginning or origin of the world it is really different from the views stated by historians, scientists, and archaeologists. The story mentioned in the text cannot be verified scientifically, since it is only mythological or legendary account. The text also never mentions how animal kingdom was started. However, we can take a moral lesson from what the text has described. From the text, we can see that greed tendency among those beings is really the main cause of the problem environmental change. Due to their greed, those beings finally had to accept their consequences, namely lost their self luminosity and the appearance of moon, sun etc. Though, such a discourse may be far from what so called historical facts, but we can see the moral value from what the text want to convey. In the modern time, greed, arrogance and other psychological tendencies among human beings which are really the main cause of environmental problem. Such idea can be seen from the continuity of the text which states thus,

"And those being continued for a very long time feasting on this savoury earth, feeding on it and being nourished by it. And as they did so, their bodies became coarser, and a difference in looks developed among them. Some beings became good-looking, others ugly. And the good-looking ones despised the others, saying "We are better-looking than they are." And because they became arrogant and conceited about their looks, the savoury earth disappeared. At this they came together and lamented, ......."20

Here once again we can make a statement that our unwholesome psychological tendencies can give unwholesome impact towards our natural surrounding. It may not give the impact directly, but sooner or later our natural surrounding will get the effect due to our greed, arrogance etc. Thus, as far as human beings do not control their unwholesome tendencies, environmental problem cannot really be solved properly. Therefore we can refer from the same text which illustrates further. The text then mentions that after the savory earth had disappeared, a fungus, in the manner of a mushroom appeared. So the beings then started to feed on this new form of food. As a result, their bodies became coarser and the difference of their looks increased more. As in the earlier stage, the good-looking ones despised the others, and thus arrogance became more existed among them. Furthermore it is said that due to their arrogance and

\footnotetext{
${ }^{20}$ Walshe, Maurice. 1995. The Long Discourse of the Buddha. Kandy: Buddhist Publication Society. p. 27
} 
conceited, the fungus disappeared which then gave rise to the appearance of creepers which were shooting up like bamboo. Finally, those beings were said to feed on those new forms of food, the creepers.

As the same aforementioned, after feeding on those creepers, their bodies became coarser and the difference in their look increased still more. They also became more arrogant. Due to they became more arrogant, the creepers then disappeared. Of course those beings lamented for what had happened, but their lamentation did not change the situation at all. However, then it is said that after the creepers had disappeared, rice which was free from powder and husks, fragrant and cleaned-grained appeared in open spaces.

As we can guess, those beings then depended and fed on the rice which appeared in open spaces. It is said that when they took the rice for supper in the evening, the rice had grown in next morning and when they took the rice for breakfast in the morning, the rice had grown and was ripe in the evening. Those beings feed on the rice for very long period of time. The text then mentions that after they fed on the rice, not only their bodies became coarse and the difference in their looks became even greater, but also the difference of their sexual organ became appeared. After that, the women became excessively preoccupied with men, the men with women. As a result, their bodies were burn with lust which then led them to commit sexual activities. In this stage, beings who committed sexual activities were regarded as a very bad thing, and therefore they started to build dwelling to hide their sexual indulgence.

It is also said that laziness then were prevalent among them. Due to this laziness tendency, this really gives serious impact towards environmental condition, since it led those beings started to hoard the rice for their meal. The text mentions as follows,

"Now it occurred to one of those beings who was inclined to laziness: "Well now, why should I be bothered to gather rice in the evening for supper and in the morning for breakfast? Why shouldn't I gather it all at once for both meals?" And he did so. Then another one came to him and said: "Come on, let's go rice gathering." "No need my friend, I've gathered enough for both meals." Then the other following his example, gathered enough rice for two days at a time, saying: "That should be about enough." Then another being came and said to that second one: "Come on let's go rice gathering." .......... However, when those beings made a store of rice and live on that, huskpowder and husk began to envelop the grain, and where it was reaped it did not grow again, and the cut place showed, and the rice grew in separate clusters." 21

${ }^{21}$ Walshe, Maurice. 1995. The Long Discourse of the Buddha. Kandy: Buddhist Publication Society. p. 27 
The above mentioned story may not be historically true, but there is a hidden message behind the story for our humanity in this modern era. In modern time, almost every environmental problem is started with greed and other psychological factors, especially human greed for everything. Of course these psychological factors can be manifested through the political and economic factors, but when we trace to the very basic root of the problem, those factors have greed and other psychological tendency as the main cause. Thus, the idea which is stated in the Agganna sutta of the Digha Nikaya about the negative effect of greed and other psychological tendency has something to say for the establishment of environmental conservation. In other words, despite lacking a concept of theistic creation, Buddhism as one of world religions has something to say about an environmental philosophy.

Based on the above mentioned narration, we can also see the emphasis on the notion of dependent origination or interconnectedness which is highly emphasized very much in Buddhism. According to Buddhism, everything occurs due to conditions or various factors. From what has been stated above, we can see the evolutionary process advocated by Buddhism as the consequence of the working of the law of dependent origination or interconnectedness. For instance, the discourse states that the disappearance of former food and the occurrence of new food is due to interconnected factors. Especially, human beings in certain case are responsible for the changing process of what happen in nature. It is in such a concept that Buddhism always give explanation about the occurrence of everything. In that way, Buddhism will never advocate the idea of a first cause nor the view of a single factor. That is why, the concept of dependence origination or interconnectedness (Paticcasamuppada) becomes the central teaching in Buddhism.

\section{Buddhist attitude towards nature and animal}

Basically early Buddhism is in a agreement with the idea of conserving environment. In several occasions, the importance of environment for every individual is highlighted. It is said that living in a suitable environment is regarded as one of the auspicious things. ${ }^{22}$ The Commentary explains that it is as a place where fourfold people namely where monks, nuns, lay male devotees and lay female devotees live, where meritorious deeds such as liberality prevail

\footnotetext{
${ }^{22}$ H. Saddhatissa. (trans1.) 1985. The Sutta Nipata. London: Curzon Press. p.29
} 
and where the teachings of truth are taught and studied. ${ }^{23}$ Such a place is called auspicious because people living in such areas are in position to acquire merit. ${ }^{24}$ Early Buddhism recognizes the fact that environment plays an importance part in the moulding of the character of individuals as well of the group, though it does not believe that it is the one and the only factor. There is an emphasis to the need for every human being to attain a greater understanding of the nature of the world through spiritual development. Moreover, in various ways, the Buddha has stressed the need for close contact with one's environment and pointed out how advancement of mind leads to a greater appreciation of one's environment. In the Dhammapada it is stated thus;

"Delightful are the forest

Where ordinary people find no pleasure

There the passionless will rejoice

For they seek no sensual pleasures." 25

It is also said that meditation as one of the most important teachings in Buddhism, is possible unless the proper environment is there. A person who is keen on cultivating higher virtues to develop the mind has to withdraw to a place where suitable environment conditions are found. The place mentioned as very favorable for meditation are a remote wilderness, the foot of a tree, a mountain range, a rock cave, a cemetery, a secluded place away from human habitation, an open space and a heap of straw. ${ }^{26}$ However, there is possibility that the appreciation of Buddhism towards natural phenomena like forest, mountain etc. are derived from pre-Buddhist tradition. It is said that prior to the rise of Buddhism, people regarded natural phenomena such as mountains, forests, groves and trees with a sense of awe and reverence. ${ }^{27}$ People at the time considered them as the abode of powerful non-human beings who could assist human beings at the time of need. Though Buddhism does not accept this idea fully, the places continued to enjoy public patronage at a popular level. Therefore among the Buddhists there is a reverential

\footnotetext{
${ }^{23}$ Ho. Smith (ed). 1915. Khuddhakapatha Atthakatha. London: Pali Text Society. p. 132

24 Ratanasara, Pallegama, Ven. 2000. The Buddhist Concept of the Environment and Individual, Kuala Lumpur: Buddhist Maha vihara. P. 12

${ }^{25}$ Narada. 1993. The Dhammapada. Taiwan: The Corporate Body of the Buddha educational Foundation. P. 94

${ }^{26}$ Nanamoli, Bhikkhu and Bhikkhu Bodhi. 1995. The Middle Length Saying of Buddha. Kandy: Buddhist Publication Society. p. 875

${ }^{27}$ Ibid.
} 
attitude towards specially long-standing gigantic trees. They are called vanaspati in Pali which means "lords of the forest". 28

Furthermore, there are many instances in which the Buddha and his disciples appreciate the beauty of their surrounding environment. They regarded natural beauty a source of great joy and aesthetic satisfaction. The utterance of their great appreciation to the beauty of nature was born out of attachment. For example, Ven. Mahakassapa is said to utter thus;

"Those upland glades delightful to the soul, Where the Kaveri spreads its wildering wreaths, Where sound the trumpet-calls of elephants: Those are the hills where my soul delights. Those rocky heights with hue dark blue clouds Where lies embossed many a shining lake Of crystal-clear, cool waters, and whose slopes The "herds of Indra' cover and bedeck: Those are hills wherein my soul delights. Fair uplands rain-refreshed, and resonant With crested creatures' cries antiphonal, Lone heights where silent Rishis oft resort: Those are the hills wherein my soul delights. ${ }^{29}$

There was also a monk named Kaludayi who uttered the appreciation of the beauty of nature in autumn. He did so for reminding the Buddha to leave for the Buddha's birth place, Kapilavatthu which was never visited by him more than six years since his departure for the sake of attaining enlightenment. The verses are as follows;

The delightful trees in bloom diffuse their scent all around, all direction Having shed their petals, hoping for fruits.

It is time to go forth from here

Trees are now crimson Lord, Having shed their old foliage, About to fruit They seem illuminate as though aflame. The time partakes of flavor, O Great Hero. ${ }^{30}$

It is also said that after listening this, the Buddha then was willing to go. However, what is expected here is that Buddhist people should not misunderstand about what the texts have

\footnotetext{
${ }^{28}$ Ibid

${ }^{29}$ Pischel (ed). 1883. Theraghata. London: Pali Text Society. v 1062-1071

${ }^{30}$ Ibid
} 
stated. The text should not be interpreted as a foundation for everybody to live in the forests and then neglecting their real duties to the society in general.

In addition to the above mentioned clarification, we can find abundant materials in the Buddhist scriptures which express the love of animals. One example is the Fu-pen-hsing-chiching, ${ }^{31}$ one of the Mahayanist written in Mandarin which depicts a story of the following. When the Buddha was still a child, it is said that Devadatta, one of his cousins, shot a flying goose with an arrow. The goose fell down to earth, of course Devadatta tried to get it. However, Prince Siddhartha said that he would try to cure the wound of the goose. He then also said that if the goose didn't die the goose belonged to him, and if it died, it would belong to Devadatta. Unfortunately the goose stayed alive due to Prince Siddhatha's help and after sometime, it was let to fly again. This story shows how the Buddhist scripture depicts about the attitude Buddhism towards animals. Here, love and care are emphasized very much.

In the Suvarnaprabhasa Sutra, ${ }^{32}$ there is also another story that reflects Buddhism's love towards animals. One day it is said that when the Buddha was still a Bodhisattva (Buddha to be), he went with his two elder brothers to play in the mountains. While they were playing they came upon a tigress, which had given birth to seven cubs. She looked very weak and emaciated and was dying of starvation. The two elder brothers felt sorry for her but, realizing the dangerous situation, ran away. However, the bodhisattva thought that it was time for him to practice compassion, one of the perfections, which he aspired to fulfill. So, on that occasion, he threw himself in front of the tigress, and let himself be eaten by her. Here once again love and compassion towards animals are stressed upon in the Buddhist texts.

Along with these examples there are still an abundance of stories and teaching found in the Buddhist scripture, which express about love towards animals. In addition, one of the precepts, which should be observed by Buddhists, is to refrain from killing any living beings, including animals. It shows that respect for any form of life, including animals, is given a great significance. In every case, one should make standards for oneself in deciding how to treat others. In the Dhammapada, one of the Buddhist scriptures, the Buddha gives the following advice:

"I myself tremble at violence, wish to live in peace and do not want to die. Thus, putting myself in the place of others, I should

\footnotetext{
${ }^{31}$ Editted by Malasekera G.P. (Ed)1956. Encyclopaedia of Buddhism Vol. 1. Government of Sri Lanka. p. 670 ${ }^{32}$ Ibid.
} 
recognize that all other beings tremble at violence, that all wish to live and do not want to die. Recognizing this, I should not intimidate others, harm them, or cause them to be harmed in any way (Dhammapada, vv. 129-130).

Thus, basically it can be said that Buddhism is an eco-friendly religion. Moreover, Buddhism, especially Mahayana Buddhism, recognizes that animals also have Buddha nature like human beings as well. It means that animal has a potentiality to be an enlightened one or a Buddha sooner or later. That is why any form of wrong action, which involves any harmful action toward animals such as sacrificial offerings or obtaining their meat for any reason are never suggested in Buddhist scriptures. Furthermore, selling flesh, poison, animal to be killed, and other things which are related to animal exploitation is regarded as wrong livelihood in Buddhism. ${ }^{33}$ Therefore, even now we can still find a ceremony of releasing life in certain Buddhist monasteries. ${ }^{34}$ It is a ceremony to help animals which are about to be slaughtered or killed by people. In addition to this, the Buddha gave certain "condition" with regard to meat which can be eaten by his followers. The condition is that the they must be certain that it is "free in three ways". That is, they have not seen that the animal was killed for him; nor have heard that the animal was killed for them; nor they have apprehension or doubt that the animal was killed for them. ${ }^{35}$ Moreover, the expression of "May all living beings be happy" which is taken from Metta Sutta, ${ }^{36}$ one of the Buddhist discourses, can be found out throughout all Buddhist traditions. The expression shows the care, concern, and love of Buddhism towards all living beings, including animals.

However, in the context of social life and the need for human survival, the Buddhist followers, especially in Indonesian context, have interpreted differently what is stated in the scriptures. It is agreeable when Willis Jenkins says that the involvement of religious institutions and thinkers in developing the idea of sustainability raises question about how to think of the relation between religion and sustainability. ${ }^{37} \mathrm{He}$, quoting from Lubchenko's et al's article, also says that investigating the connection between social problems and ecological systems represents

\footnotetext{
${ }^{33}$ Abenayake, Oliver. 1995. Fundamental of Buddhist Polity. Singapore: Tisarana Buddhist Association. p. 97

${ }^{34}$ Malasekera G.P. (ed) 1956. Encyclopaedia of Buddhism Vol. 1. Government of Sri Lanka p.671

${ }^{35}$ Upasak, C.S. 1975. Dictioanary of Early Buddhist Monastic Terms. Varanasi: Bharati Prakashan. p. 177

${ }^{36}$ Kaza Stephanie (ed). 2000. Dharma Rain. Boston \& London: Shambala. pp. 29-30

${ }^{37}$ Jenkins, Willis. 2010. Sustainability in Grounding Religion, A Field Guide to Religion and Ecology. Routledge. p. 139
} 
a scientific research program as well as a project of cultural and ethical reflection. ${ }^{38}$ In relation with his idea, Buddhist people have adapted their religious scriptures with the situation and condition in which they live. This idea shows the need for survival influences how the Buddhist people interpret the scriptures, especially about the precept of not killing any living beings and the teaching of wrong livelihood. At present we can see that some Buddhist people raise animals such as chickens, goats, buffalo, cows and other animals. They sometimes even involve in fish farming. The main purpose of such a activity is to uplift the economic condition of the family because they cannot find any other occupation. Sometimes, they also will kill or slaughter the animals to obtain meat for their own family and to sell to other people. Moreover, those who are farmers sometimes also use any kind pesticide or poisons to kill animals or pests harmful for their plant cultivations. Moreover, they also sometimes use certain animals for traditional medical purposes, like worms for curing typhus, bats for curing asthma etc. In addition to this, in certain countries like Sri Lanka and Thailand where the majority of the population are Buddhist people, fish farming and animal husbandry cannot be avoided. Thus, Fernando while discussing about the impact of Buddhism on the small-scale fishery in Sri Lanka rightly says,

"Sri Lanka is a predominantly Buddhist country where approximately 68 percent of the people are Buddhists. Non-violence to living beings is a cornerstone of Buddhist theory it is a vital component of the state of spiritual attainment toward which all Buddhists are expected to strive. However, in Sri Lanka society - as in all Buddhist societies - the slaughter of animal for food is part of empirical reality." 39

N. J. De Silva Amarasinghe, a lecture from University of Ruhuna in Sri Lanka, also recognizes that economic reasons are the main reason for Buddhist in interpreting their religious texts. He says,

"The very first of the Five Precepts which calls on Buddhists to refrain from killing living beings, in fact, presupposes the existence of slaughter trades such as fishing and people who are engaged in them. It is also clear that although doctrinally the slaughter of fish was considered incompatible with the above precept, fishing as an occupation has been a social reality in our country from time immemorial. Today, there are individuals from traditionally Buddhist families engaged in the fishing industry, most of whom intellectually accept the position that there is a break of the First Precept when they take part in the slaughter of fish. Economic needs appear to outweigh the culture and religious factors in determining the economic behavior of the low income groups and attitudes the

\footnotetext{
38 ibid

${ }^{39}$ Fernando S., L. Devasena, R. M. Ranweera Banda \& H. K. M. Somawantha (1985). Impact of Buddhism on the small-scale fishery of Sri Lanka. In: Small-scale Fisheries in Asia - Socioeconomic Analysis and Policy (T.

Panayotou (ed.). International Development Research Centre, Canada).
} 
consumption of animal flesh is changing. (http://www.fao.org/docrep/004/ac155e/AC155E17.htm)

In Sri Lanka, in spite of the government getting pressure from the Buddhist leaders in the country who always publicly despise killing of animals, the state involvement in the marine fisheries sector was not curtailed in any way; the government continues to operate its subsidy schemes for distributing fishing boats and gill nets and its program to develop existing fishing harbors and to establish new ones. ${ }^{40}$

In Thailand, it is not different from what happens in Sri Lanka. It is said that the importation of animal feed in Thailand for the purpose of raising animals and fish farming is increasing year by year (http://www.ats.agr.gc.calase/4774-eng.htm). This shows that in Thailand also where the majority of the population is Buddhists, the country does not withdraw away from raising animals and fish farming in which slaughtering or killing animals cannot be avoided.

\section{The concept of destruction of the world}

In Buddhism, the idea of destruction in this world or the end of the world is never related to the notion of God or any supernatural being. The destruction and the end of the world are considered as just two forms of changing phenomena which always happen in all conditioned things. In Buddhism, there is a teaching which states that every conditioned or constructed thing is impermanent. Therefore, according to Buddhism, one is supposed not to have psychological attachment or clinging to any impermanent things, because it will be the cause of one's mental suffering. In such a case, the idea of detachment to impermanent things is encouraged for the sake of experiencing inner peace which is usually experienced through certain mental training. In certain occasion, the phenomenon of impermanency of all conditioned things is used by the Buddha to advise his disciples to be vigilant and hard working. For example, once the Buddha says to one his monk disciples as follows,

"See, Ananda, how all those conditioned states of the past have vanished and changed! Thus, Ananda, conditioned states are impermanent, they are unstable, they can bring us

\footnotetext{
${ }^{40}$ Fernando S., L. Devasena, R. M. Ranweera Banda \& H. K. M. Somawantha (1985). Impact of Buddhism on the small-scale fishery of Sri Lanka. In: Small-scale Fisheries in Asia - Socioeconomic Analysis and Policy (T. Panayotou (ed.). International Development Research Centre, Canada).
} 
no comfort, and such being the case, Ananda, we should not

rejoice in conditioned states, we should cease to take an interest

in them, and be liberated from them. ${ }^{41}$

In another occasion, the Buddha also says as follows;

“..... monks, impermanent are the constituents of existence, unstable, non-eternal: so much so, that this alone is enough to weary and disgust one with all constituent things and emancipate there from....

So, according to Buddhism, the destruction of the world is just the sign of impermanency of conditioned things. Therefore, in one occasion the Buddha also talked about the concept which may be regarded as "the end of the world". However, according to Buddhism, the idea of the end of the world is not really the end of all forms of our lives. It is said that sooner or later, this earth will be totally destroyed, and after sometimes it will be formed again. In addition to this, in Buddhism, there is a concept of other galaxies which in certain case it also recognizes the existence of many suns in this very vast universe.

According to Buddhism, the destruction of this earth is caused by the very long draught. After sometimes, it is said that in such a long draught, there will be second sun, third, fourth, until seventh sun. It is also stated that in the end of the occurrence of the seventh sun, our earth will become just dust scattered in the universe. According to Cornelis Wowor in his Ketuhanan Yang Maha Esa, the occurrence of the second sun and so on does not happen not accidentally, but it is because there are other suns in the universe which rotate not in accordance with their orbits. $^{43}$

In one of the Buddhist texts, the end of the world (earth) is stated as follows:

"Now there comes, O monks, a season when, after many years, many hundreds and thousands and hundreds of thousands of years, it does not rain; and while it rains not, all seedlings and vegetation, all plants, grasses, and trees dry up, wither away and cease to be. Thus, monks, constituent things are impermanent, unstable, non-eternal: so much so, that this alone is enough to weary and disgust one therewith and emancipate there from.

And, monks, there comes a season, at vast intervals in the lapse of time, when a second sun appears.

\footnotetext{
${ }^{41}$ Ibid

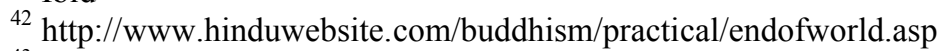

${ }^{43}$ Wowor, Cornelis. 1984. Ketuhanan Yang Maha Esa dalam Agama Buddha. Jakarta: Akademi Buddhis Nalanda. p. 8
} 
After the appearance of the second sun, monks, the brooks and ponds dry up, vanish away and cease to be. So impermanent are constituent things! And then, monks, there comes a season, at vast intervals in the lapse of time, when a third sun appears; and thereupon the great rivers: to wit, the Ganges, the Jamna, the Rapti, the Gogra, the Mahî,-dry up, vanish away and cease to be.

At length, after another vast period, a fourth sun appears, and thereupon the great lakes, whence those rivers had their rise: namely, Anotatto, Lion-leap, Chariot-maker, Keelbare, Cuckoo, Six-bayed, and Slow-flow, dry up, vanish away, and cease to be.

Again, monks, when, after another long lapse, a fifth sun appears, the waters in the great ocean go down for an hundred leagues; then for two hundred, three hundred, and even unto seven hundred leagues, until the water stands only seven fan-palms' deep, and so on unto one fan-palm; then seven fathoms' deep, and so on unto one fathom, half a fathom; waist-deep, knee-deep, ankle-deep. Even, O monks, as in the fall season, when it rains in large drops, the waters in some places are standing around the feet of the kine; even so, monks, the waters in the great ocean in some places are standing to the depth of kine-feet. After the appearance of the fifth sun, monks, the water in the great ocean is not the measure of a finger-joint. Then at last, after another lapse of time, a sixth sun appears; whereupon this great earth and Sineru, the monarch of mountains, reek and fume and send forth clouds of smoke. Even as a potter's baking, when first besmeared, doth reek and fume and smoke, such is the smoke of earth and mountains when the sixth sun appears.

After a last vast interval, a seventh sun appears, and then, monks, this great earth, and Sineru, the monarch of mountains, flare and blaze, and become one mass of flame. And now, from earth and mountains burning and consuming, a spark is carried by the wind and goes as far as the worlds of God; and the peaks of Mount Sineru, burning, consuming, perishing, go down in one vast mass of fire and crumble for an hundred, yea, five hundred leagues. And of this great earth, monks, and Sineru, the monarch of mountains, when consumed and burnt, neither ashes nor soot remains. Just as when ghee or oil is consumed and burnt, monks, neither ashes nor soot remains, so it is with the great earth and Mount Sineru."

Thus, like in other religions such as Islam and Christianity, there is recognition in Buddhism that this earth finally will come to an end. In other words, sooner or later, this earth will be vanished. However, it does not mean that there is no necessity to protect this earth from any problems which may occur. In spite of the impermanency which will be faced by this earth sooner or later, human beings do not have any rights to destroy this earth with all of its contents from extinction. In fact, the impermanency which becomes one of the characteristics of this

\footnotetext{
${ }^{44}$ http://www.hinduwebsite.com/buddhism/practical/endofworld.asp acceses on the 2nd of Mei 2011
} 
earth should give the idea for all of us to prevent everything from extinction. As we know, extinction is forever, and there will be no chance to renew something which has been extinct.

\section{Conclusion}

I hope I have described and analyzed the Buddhist concept on God, the beginning of the world, nature, and destruction of this world. Based on the above mentioned discussion, basically there are some concepts in Buddhism which have common features with those of other religious traditions, especially in Islam and Christianity. In particular, regarding the idea of impermanency of this earth, Buddhism also maintains that this earth sooner or later will come to an end. That is why there are no reasons to expect that this earth or world will be everlasting forever. However, according to Buddhism there is no any involvement of God in such destruction. Such a phenomenon is just regarded as a natural occurrence due to the impermanency character of every conditioned thing. The end of the world is just a proof that as a conditioned thing, the world is not free from destruction.

With regard to the preservation of nature, Buddhism has also something in common with Islam and Christianity. Especially when we talk about the importance of preserving the natural world, Buddhism is not different either. In fact, there are certain concepts in which Buddhism will uphold that everything in this world exist not only for human being. Buddhism recognizes that in this vast universe there is an interconnected realm in which there is none who is superior or inferior. All living beings, both human beings and animals, are considered as those who struggle to attain liberation from the long process of circle of rebirth. Based on such a concept, there is no teaching in Buddhism which asks people to kill or harm animals. Similarly with regards to trees or plants, Buddhism emphasizes the same concept. Thus, those things actually can be an instrument for all religious people to protect our environments around us. It is not only for our own sake, but also for the sake of the existence of this earth.

However, when we talk about the concept of God especially in early Buddhism, it is somewhat different from those Islamic and Christian traditions. Since Buddhism recognizes the existence of natural law which exist in the universe, every natural phenomenon is never explained by referring to the idea of God. Therefore, there are many instances in which Buddhism criticizes the notion of Supernatural Being belonging to Brahmanic tradition which is 
considered to be responsible for whatever exists in nature. For example, the idea of creation which is put forward by Brahmanism or Hinduism is criticized for just being following successive traditions or speculation which may be lacking any verification or experimental basis. ${ }^{45}$ Therefore, it is also in the same line when Buddhism discusses the concept of the beginning of the world. Buddhism never includes the concept of God in the narration about the beginning of the world. It only relates the involvement of the mythological and legendary aspects to explain the evolutionary process of what happen with this world. According to Buddhism, whatever happens in this universe, including the occurrence of this world is due to the law of interconnectedness or interdependence (Paticcasamppada). It highlights the absence of the idea of first cause and the notion of only a single factor for the occurrence of everything in the universe. Thus, it is in such a way that Buddhism always uses the concept of interconnectedness as a method to explain every phenomenon which takes place around us.

\footnotetext{
${ }^{45}$ Walshe, Maurice. 1995. The Long Discourse of the Buddha. Kandy: Buddhist Publication Society. pp. 187-195
} 


\section{References:}

Abenayake, Oliver. 1995. Fundamental of Buddhist Polity. Singapore: Tisarana Buddhist Association

Andersen, D and H. Smith (ed). 1913. The Sutta Nipata. London: Pali Text Society.

Bodhi, Bhikkhu. 2000. The Connected Discourse of the Buddha; a New Translation of the Samyutta Nikaya. Boston: Wisdom Publications.

Eliade, Mircea. 1975. Myth and Reality. London: Harper Colophon Books

Fausboll, V. (ed). 1962, Jataka, Vol V. London: Pali Text Society

Feer, M.Leon (Ed). 1960. Samyutta Nikaya Vol. II London: Pali Text Society

Fernando S., L. Devasena, R. M. Ranweera Banda \& H. K. M. Somawantha (1985). Impact of Buddhism on the small-scale fishery of Sri Lanka. In: Small-scale Fisheries in Asia -

Socioeconomic Analysis and Policy (T. Panayotou (ed.). International Development Research Centre, Canada).

H. Saddhatissa (transl.) 1985. The Sutta Nipata. London: Curzon Press

Ho. Smith (ed). 1915. Khuddhakapatha Atthakatha. London: Pali Text Society

http://majalah.tempointeraktif.com/id/arsip/1974/05/18/AG/mbm.19740518.AG64564.id.html accessed on the 22 of December 2010

http://www.hinduwebsite.com/buddhism/practical/endofworld.asp acceses on the 2nd of Mei 2011

http://www.scribd.com/doc/36895436/Adi\%C2\%A0Buddha\%C2\%A0Dalam\%C2\%A0Agama\% C2\%A0Buddha\%C2\%A0Indonesia, accessed on 21 December 2010

Jenkins, Willis. 2010. Sustainability in Grounding Religion, A Field Guide to Religion and Ecology. Routledge

Kalupahana, David J., 1976, Buddhist Philosophy A Historical Analysis. Honolulu: The University Press of Hawaii

Vishva Lekha Publications 1999. The Buddha and the Concept of Peace. Sri Lanka: Sarvodaya

Kaza Stephanie (ed). 2000. Dharma Rain. Boston \& London: Shambala 
Ling, T.O. 1962. Buddhism and The Mythology of Evil. London: George Allen \& Unwin Ltd Malasekera G.P. (ed) 1956. Encyclopaedia of Buddhism Vol. 1. Government of Sri Lanka Nanamoli Bhikkhu dan Bhikkhu Bodhi (Transl.). 1995. The Middle Length Discourse of the Buddha; a New Translation of the Majjhima Nikaya. Kandy: Buddhist Publication Society

Narada. 1993. The Dhammapada . Taiwan: The Corporate Body of the Buddha Educational Foundation

Pischel (ed). 1883. Theraghata. London: Pali Text Society

Ratanasara, Pallegama, Ven. 2000. The Buddhist Concept of the Environment and Individual, Kuala Lumpur: Buddhist Mahavihara

Upasak, C.S. 1975. Dictioanary of Early Buddhist Monastic Terms. Varanasi: Bharati Prakashan

Walshe, Maurice. 1995. The Long Discourse of the Buddha. Kandy: Buddhist Publication Society

Woodwards, F.L (Translt.) 1932. The Book of Gradual Sayings Vol. !. London: Pali Text Society

Wowor, Cornelis. 1984. Ketuhanan Yang Maha Esa dalam Agama Buddha. Jakarta: Akademi Buddhis Nalanda. 